\title{
Temperature and the development rates of thrips: Evidence for a constraint on local adaptation?
}

\author{
DAVID A. STACEY ${ }^{1}$ and MARK D.E. FELLOWES ${ }^{2 *}$ \\ ${ }^{1}$ NERC Centre for Population Biology, Imperial College at Silwood Park, Ascot, Berkshire SL5 7PY, UK \\ ${ }^{2}$ School of Animal and Microbial Sciences, University of Reading, P.O. Box 228, Whiteknights, Reading, Berkshire, RG6 6AJ, UK
}

Key words. Body size, day degrees, development rate, temperature, trade-off, Thysanoptera, Frankliniella occidentalis, Thrips major, Thrips tabaci

\begin{abstract}
Typically, the relationship between insect development and temperature is described by two characteristics: the minimum temperature needed for development to occur $\left(\mathrm{T}_{\min }\right)$ and the number of day degrees required (DDR) for the completion of development. We investigated these characteristics in three English populations of Thrips major and T. tabaci [Cawood, Yorkshire

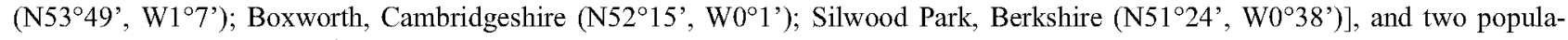
tions of Frankliniella occidentalis (Cawood; Silwood Park). While there were no significant differences among populations in either $\mathrm{T}_{\min }$ (mean for $T$. major $=7.0^{\circ} \mathrm{C} ;$ T. tabaci $=5.9^{\circ} \mathrm{C} ; \mathrm{F}$. occidentalis $=6.7^{\circ} \mathrm{C}$ ) or DDR (mean for T. major $=229.9 ; T$. tabaci $=260.8$; $F$. occidentalis $=233.4$ ), there were significant differences in the relationship between temperature and body size, suggesting the presence of geographic variation in this trait. Using published data, in addition to those newly collected, we found a negative relationship between $\mathrm{T}_{\min }$ and DDR for $F$. occidentalis and $T$. tabaci, supporting the hypothesis that a trade-off between $\mathrm{T}_{\min }$ and DDR may constrain adaptation to local climatic conditions.
\end{abstract}

\section{INTRODUCTION}

The distribution of many insect species is limited by temperature (Jeffree \& Jeffree, 1994; Baker et al., 1996; Cannon, 1998) Insects cannot develop below a threshold temperature and they need to accumulate enough day degrees to complete their life cycle (Campbell et al., 1974; Lamb, 1992; Gilbert \& Raworth, 1996; Addo-Bediako, 2000; Danks, 2000). Since the relationship between an insect's development rate and temperature is essentially linear within favourable temperatures, these values can be estimated by using linear regression (Honěk, 1996). Here, $\mathrm{R}=a \mathrm{~T}+b$, where $\mathrm{R}$ is the development rate, $\mathrm{T}$ is temperature, $b$ is the intercept and $a$ is the slope of the regression. The day degree requirement (DDR) equals $1 / a$ and the threshold development temperature $\left(T_{\min }\right)$ is equal to $-b / a$ (Honěk, 1996).

$\mathrm{T}_{\min }$ and DDR are frequently used to explain the distribution and abundance of insect species, particularly in insect pest management, where potential threats due to range expansion through accidental introduction or climate change are ever present Potentially misleading inferences on potential changes in distribution may be made if conclusions are drawn from one study, simply because the relationship between temperature and insect development rates may vary across individuals, populations and species (Campbell et al., 1974; Trimble \& Lund, 1983; Trudgill, 1995; Danks, 2000).

However, it has been suggested that DDR and $T_{\min }$ are not independent; selection on one trait may have a correlated effect on the other (Tauber et al., 1987; Trudgill, 1995). For example, it has been proposed that species living closer to the poles have a lower $T_{\min }$, but a greater DDR, while those nearer to the equator show the reverse pattern (Trudgill, 1995; Honěk, 1996). A similar suggestion has been made for species that emerge in the spring (lower $\mathrm{T}_{\min }$, higher DDR) and summer (higher $\mathrm{T}_{\min }$, lower DDR) in temperate regions (Gilbert \& Raworth, 1996). In consequence, when we compare across species, we should find a negative relationship between $T_{\min }$ and DDR (Trudgill, 1995; Honek, 1996). Within species, the patterns are less clear, although there is some evidence of such trade-offs in the green lacewing, Chrysopa oculata (Tauber et al., 1987). Such tradeoffs may constrain local adaptation, as a reduction in $\mathrm{T}_{\min }$ will be associated with an increase in DDR.

These trade-offs may also inform the continuing debate on why evidence for insect local adaptation to climatic conditions is so unclear. While several studies appear to show adaptation (e.g. Tauber \& Tauber, 1978; Trimble \& Lund, 1983; Ayres \& Scriber, 1994; Telfer \& Hassell, 1999; Birkemoe \& Leinaas, 2001), there are others that show no variation in thermal requirements over a wide geographic range (Baker \& Miller, 1978; Lamb et al., 1987; Tauber et al., 1987; Royer et al., 2001). This contrasts with the wide evidence for insect adaptation to other environmental factors, such as host plant species and photoperiod (Lamb et al., 1987).

To examine whether geographic origin influenced estimates of thrips $\mathrm{T}_{\min }$ and DDR, we collected three species [Thrips tabaci Lindeman, Thrips major Uzel (providing the first study of temperature relations in this species) and Frankliniella occidentalis Pergande] from three locations in England, and asked three questions. First, is there evidence for variation in $T_{\min }$ and/or DDR among these thrips populations? Second, does the relationship between body size (measured as forewing length) and temperature vary among these populations? Third, using the data collected here and previously published work, we asked if there was evidence of a trade-off between $\mathrm{T}_{\min }$ and DDR for $F$. occidentalis and T. tabaci.

\section{MATERIALS AND METHODS}

\section{Study species}

Frankliniella occidentalis (Thysanoptera: Thripidae) is native to North America, and was introduced into the UK in the 1980s (EPPO/CABI, 1992). It has become a major pest of field and

\footnotetext{
* Corresponding author. E-mail: m.fellowes@reading.ac.uk; tel: +44 188987 5123; fax: +44 1889310180.
} 
TABLE 1. $\mathrm{T}_{\min }$, DDR and experimental details for studies of the thermal relations of $F$. occidentalis (F. occ.), Thrips tabaci (T. tab.) and T. major (T. maj.).

\begin{tabular}{|c|c|c|c|c|c|c|c|}
\hline $\begin{array}{l}\text { Thrips } \\
\text { species }\end{array}$ & Host plant $^{1}$ & $\begin{array}{l}\text { Temp. } \\
\text { range }\end{array}$ & $\begin{array}{l}\text { Light condi- } \\
\text { tions }\end{array}$ & $\mathrm{T}_{\min }$ & DDR & Thrips origin $^{2}$ & Author \\
\hline F. occ. & Green bean pods ${ }^{\mathrm{B}}$ & $12-28^{\circ} \mathrm{C}$ & $16 \mathrm{~L}: 8 \mathrm{D}$ & $6.6^{\circ} \mathrm{C}$ & 228.8 & UK, Yorkshire & This study \\
\hline F.occ. & Green bean pods ${ }^{\mathrm{B}}$ & $12-28^{\circ} \mathrm{C}$ & $16 \mathrm{~L}: 8 \mathrm{D}$ & $6.8^{\circ} \mathrm{C}$ & 238.0 & UK, Berkshire & This study \\
\hline F. occ. & Green bean leaves ${ }^{\mathrm{B}}$ & $15-30^{\circ} \mathrm{C}$ & $15 \mathrm{~L}: 9 \mathrm{D}$ & $5.3^{\circ} \mathrm{C}$ & 303.03 & USA, Texas & Lublinkhof \& Foster, 1977 \\
\hline F. occ. & $\begin{array}{c}\text { Chrysanthemum mor- } \\
\text { rifolium }\end{array}$ & $15-30^{\circ} \mathrm{C}$ & $18 \mathrm{~L}: 6 \mathrm{D}$ & $9.5^{\circ} \mathrm{C}$ & 194 & Japan & Katayama, 1997 \\
\hline F. occ. & $\begin{array}{c}\text { Chrysanthemum spp. } \\
\text { leaves }\end{array}$ & $10-30^{\circ} \mathrm{C}$ & $18 \mathrm{~L}: 6 \mathrm{D}$ & $7.9^{\circ} \mathrm{C}$ & 268 & UK & McDonald et al., 1998 \\
\hline F. occ. & $\begin{array}{c}\text { Chrysanthemum spp. } \\
\text { leaves }\end{array}$ & $15-30^{\circ} \mathrm{C}$ & unknown & $11.8^{\circ} \mathrm{C}$ & 169.5 & USA & Robb \& Parrella, 1991 \\
\hline F. occ. & Cucumber leaves ${ }^{\mathrm{s}}$ & $18-31^{\circ} \mathrm{C}$ & $16 \mathrm{~L}: 8 \mathrm{D}$ & $10.7^{\circ} \mathrm{C}$ & 231.1 & $\begin{array}{l}\text { Czech Rep., } \\
\text { Bohemia }\end{array}$ & Jarošík et al., 1997 \\
\hline F. occ. & Cucumber leaves $^{\mathrm{C}}$ & $15-28^{\circ} \mathrm{C}$ & $16 \mathrm{~L}: 8 \mathrm{D}$ & $10.9^{\circ} \mathrm{C}^{3}$ & - & $\begin{array}{l}\text { Netherlands, } \\
\text { Wageningen }\end{array}$ & van Rijn et al., 1995 \\
\hline F. occ. & Cucumber leaves $^{P}$ & $15-30^{\circ} \mathrm{C}$ & $16 \mathrm{~L}: 8 \mathrm{D}$ & $9.4^{\circ} \mathrm{C}$ & 249.8 & South Africa & Gaum et al., 1994 \\
\hline F. occ. & Peanut leaves ${ }^{F}$ & $20-30^{\circ} \mathrm{C}$ & unknown & $6.5^{\circ} \mathrm{C}$ & 253.9 & USA & Lowry et al., 1992 \\
\hline F. occ. & Radish leaves & $15-26.7^{\circ} \mathrm{C}$ & unknown & $9.4^{\circ} \mathrm{C}$ & 238.1 & USA, California & Bryan \& Smith, 1956 \\
\hline T. $t a b$. & Green bean pods ${ }^{\mathrm{B}}$ & $12-28^{\circ} \mathrm{C}$ & $16 \mathrm{~L}: 8 \mathrm{D}$ & $4.2^{\circ} \mathrm{C}$ & 296.9 & UK, Yorkshire & This study \\
\hline T. $t a b$. & Green bean pods ${ }^{\mathrm{B}}$ & $12-28^{\circ} \mathrm{C}$ & $16 \mathrm{~L}: 8 \mathrm{D}$ & $6.5^{\circ} \mathrm{C}$ & 249.9 & UK, Cambs. & This study \\
\hline T. $t a b$. & Green bean pods ${ }^{\mathrm{B}}$ & $12-28^{\circ} \mathrm{C}$ & $16 \mathrm{~L}: 8 \mathrm{D}$ & $6.9^{\circ} \mathrm{C}$ & 235.7 & UK, Berkshire & This study \\
\hline T. $t a b$. & $\begin{array}{l}\text { Pollen and honey } \\
\text { solution }\end{array}$ & $15-30^{\circ} \mathrm{C}$ & $16 \mathrm{~L}: 8 \mathrm{D}$ & $10.8^{\circ} \mathrm{C}$ & $232.6^{4}$ & Japan & Murai, 2000 \\
\hline T. tab. & Onion leaf tissue & $10-27.5^{\circ} \mathrm{C}$ & unknown & $11.5^{\circ} \mathrm{C}$ & 178.6 & USA, Texas & Edelson \& Magaro, 1988 \\
\hline T. $t a b$. & Cucumber leaves $^{\mathrm{C}}$ & $15-28^{\circ} \mathrm{C}$ & $16 \mathrm{~L}: 8 \mathrm{D}$ & $11.5^{\circ} \mathrm{C}^{3}$ & - & $\begin{array}{l}\text { Netherlands, } \\
\text { Amsterdam }\end{array}$ & van Rijn et al., 1995 \\
\hline T. maj. & Green bean pods ${ }^{\mathrm{B}}$ & $12-28^{\circ} \mathrm{C}$ & $16 \mathrm{~L}: 8 \mathrm{D}$ & $7.3^{\circ} \mathrm{C}$ & 223.9 & UK, Yorkshire & This study \\
\hline T. maj. & Green bean pods ${ }^{\mathrm{B}}$ & $12-28^{\circ} \mathrm{C}$ & $16 \mathrm{~L}: 8 \mathrm{D}$ & $6.4^{\circ} \mathrm{C}$ & 259.2 & UK, Cambs. & This study \\
\hline T. maj. & Green bean pods ${ }^{\mathrm{B}}$ & $12-28^{\circ} \mathrm{C}$ & $16 \mathrm{~L}: 8 \mathrm{D}$ & $7.4^{\circ} \mathrm{C}$ & 206.8 & UK, Berkshire & This study \\
\hline
\end{tabular}

\footnotetext{
${ }^{1}$ Variety: B - Blue lake, S - Sandra, C - Corona, P - Pipinex, F - Florunner.

${ }^{2}$ Unless otherwise stated, the origin of the thrips used was assumed to be similar to the authors' address.

${ }^{3} \mathrm{~T}_{\min }$ was calculated here using development rate data from only egg to second instar. These data were not used in the regression in Fig. 3 as DDR was unavailable.

${ }^{4} \mathrm{DDR}$ was calculated here using development rate data from egg to first oviposition.
}

protected crops around the world (Steiner \& Goodwin, 1998). It can produce as many as $12-15$ generations per year in glasshouse environments (Kirk, 1996), but has not established permanent field populations in high latitudes (McDonald et al., 1998). The onion thrips Thrips tabaci (Thysanoptera: Thripidae) is a pest of allium crops (Lewis, 1997) and was probably introduced to the UK by the Romans (L. Mound, pers. comm.). Thrips major (Thysanoptera: Thripidae) is one of the commonest thrips in the UK (Kirk, 1996). Native to the UK, it lives on a wide variety of wild flowers, and is not considered to be a significant pest species.

\section{Thrips collection and rearing}

Thrips were collected between June and July 2000 from plants at three field-sites in England: Cawood in Yorkshire

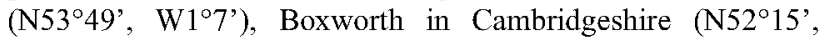
W0 $\left.{ }^{\circ} 1^{\prime}\right)$ and Silwood Park in Berkshire (N51 $24^{\prime}$, W0 $\left.38^{\prime}\right)$. All sites had a similar mix of vegetable crops and rough field margins. Plants were tapped with a stick over a white tray and any 
thrips dislodged were collected in ventilated pots. Frankliniella occidentalis was not found at the Cambridgeshire site.

Thrips were identified following Kirk (1996) and Mound \& Kibby (1998). Females of each of the study species were placed into individual ventilated pots and allowed oviposit onto organically grown green bean Phaseolis vulgaris L. (var. Blue Lake) pods for three days. The resulting larvae formed the base for the cultures used in the experiments.

Thrips were cultured in $8 \mathrm{~cm}$ diameter pots. The lids were sealed to prevent thrips escaping and a $5 \mathrm{~cm}$ diameter hole cut out, covered with white cotton fabric, to allow ventilation Washed bean pods were used as a food source and oviposition site. All three thrips species readily accepted these hosts. Three pods were placed in each pot and replaced with fresh ones when they became desiccated (after about 10 days). The thrips diet was supplemented with pollen grains. Several squares of tissue paper were provided for pupation. Cultures were kept at $20^{\circ} \mathrm{C}$ with a $16 \mathrm{~L}: 8 \mathrm{D}$ photoperiod and $70 \%$ relative humidity. The thrips were reared in these conditions for three generations to avoid maternal effects.

\section{Thrips developmental rate and body size}

Ten randomly selected female thrips from each population were left to oviposit for 24 hours in individual pots. The thrips were removed and the pots transferred to one of five temperature regimes $\left(12,15,20,25\right.$ or $\left.28^{\circ} \mathrm{C}\right)$, each with a $16 \mathrm{~L}: 8 \mathrm{D}$ photoperiod and $70 \%$ humidity. The beans were checked daily for emerging larvae. Larvae that hatched were transferred individually into glass vials ( $2 \mathrm{~cm}$ high by $2 \mathrm{~cm}$ diameter). This was repeated until no further larvae emerged, resulting in at least 10 larvae in each replicate. The vials had a $5 \mathrm{~mm}$ thick layer of agar on the bottom to prevent desiccation, which contained $2 \mathrm{~g} / 1$ of dissolved nipogen (p-hydroxy-benzoic acid) to inhibit funga growth. A $1 \mathrm{~cm}$ long piece of bean pod was placed on the agar. The lids of the vials were sealed and had a $1 \mathrm{~cm}$ diameter hole covered with cotton. Once a week the beans were replaced with fresh pods and the larval development was checked daily. The development time was noted, and $\mathrm{T}_{\min }$ and DDR calculated. The forewing of emerging females, preserved in $70 \%$ ethanol, was measured as a proxy for body size (Nakao, 1993).

\section{Literature search}

The ISI database Web of Science and several studies published prior to 1981 were searched for data on the development rates of the three thrips species. Where DDR and $T_{\min }$ values were not directly given, these were calculated from the published development rate data. The host plant, temperature range, light conditions and thrips origin for each study were also recorded.

\section{Statistical analyses}

To avoid pseudoreplication (i.e. measures of development and body size within a $\mathrm{CT}$ room are not independent), mean values $(n=10-40)$ from each CT-room (i.e. one for each of the five temperatures used) for development rate and wing length $(\mathrm{mm})$ were calculated and used in the subsequent analysis. Data were analysed using GLIM 3.77 (Crawley, 1993). Analysis of covariance, with temperature as covariate, site as the explanatory factor and wing length or development time as the response variable was performed. Linear regression was used to compare the cross-population relationships between $\mathrm{T}_{\min }$ and DDR.

\section{RESULTS}

\section{Developmental rate}

Site did not significantly affect development rate among any of the thrips species collected from the three English sites (Fig.
1; T. major: $F_{2},{ }_{11}=3.31, P=$ n.s.; $T$. tabaci: $F_{2,11}=0.24, P=$ n.s.; $F$. occidentalis: $F_{1,7}=0.78, P=$ n.s.), but there was a highly significant effect of temperature on development rate for all three species ( $T$. major: $F_{1,11}=384.3, P<0.0001 ; T$. tabaci: $F_{1,11}=265.75, P<0.0001 ; F$. occidentalis: $F_{1,7}=384.3, P<$ 0.0001). The slopes of the development rate lines for populations of each of the three species did not differ significantly from each other ( $T$. major: $F_{2,9}=1.789, P=$ n.s.; $T$. tabaci: $F_{2,9}$ $=1.26, P=$ n.s. $F$. occidentalis: $F_{1,6}=0.13, P=$ n.s. $)$, nor did the intercepts of the lines (T. major: $F_{2,11}=0.54, P=$ n.s.; $T$. tabaci: $F_{2,11}=0.91, P=$ n.s.; $F$. occidentalis: $F_{1,7}=0.01, P=$ n.s.).

\section{Body size}

Site significantly affected mean forewing length for $T$. major (Fig. $\left.2 ; F_{2,11}=17.52, P=0.0004\right)$ and $T$. tabaci $\left(F_{2,11}=17.83, P\right.$ $=0.0004)$, but not $F$. occidentalis $\left(F_{1,7}=2.81, P=\right.$ n.s. $)$. There was also a significant effect of temperature on forewing length among populations of all three species, with thrips reared at warmer temperatures generally being smaller ( $T$. major: $F_{1,11}=$ 9.51, $P=0.01 ;$ T. tabaci: $F_{1,11}=47.37, P<0.0001 ;$ F. occidentalis: $F_{1,7}=6.84, P=0.035$ ). The slopes of the wing length lines did not differ significantly from each other (T. major: $F_{2,9}=$ 1.34, $P=$ n.s.; $T$. tabaci: $F_{2,9}=1.41, P=$ n.s.; $F$. occidentalis: $F_{1}$, ${ }_{6}=3.17, P=$ n.s.), nor did the intercepts of the lines ( $T$. major: $F_{2,11}=0.55, P=$ n.s.; $T$. tabaci: $F_{2,11}=3.98, P=$ n.s.; $F$. occidentalis: $F_{1,7}=5.08, P=0.06$ ).

\section{Literature search}

We found nine examples of development rate data for $F$. occidentalis and three for T. tabaci (Table 1). No studies of T. major were found. Taking the available data, we found a significant negative relationship between day degree requirement and threshold developmental temperature for T. tabaci (Fig. $3 ; F_{1,3}=$ $\left.10.86, P=0.046, \mathrm{r}^{2}=0.78\right)$ and $F$. occidentalis $\left(F_{1,8}=9.86, P=\right.$ $\left.0.014, \mathrm{r}^{2}=0.55\right)$.

\section{DISCUSSION}

We found no differences in $\mathrm{T}_{\text {тіг }}$ or DDR among populations of the three thrips species examined. This is the first time the development rate of T. major has been published, to our knowledge. Nevertheless, there were significant differences in $T$. tabaci and $T$. major forewing length among the populations tested (and for $F$. occidentalis the intercept of the fitted lines was near to the traditional threshold significance value), suggesting that local differences are present. Body size was negatively correlated with rearing temperature in all three thrips species, a commonly reported result (Atkinson, 1994). However, the nature of the relationship varied among populations, and there was no trend between size and geographic origin. Such variation may reflect adaptation to a local host plant, rather than climatic conditions. Our survey of the literature revealed large differences in estimates of $\mathrm{T}_{\min }$ and DDR for $T$. tabaci and $F$. occidentalis. Our estimates of $\mathrm{T}_{\min }$ for $T$. tabaci are lower than any previously published. We found a negative relationship between DDR and $\mathrm{T}_{\min }$ across populations of $T$. tabaci and $F$. occidentalis, suggesting the presence of a trade-off between these traits. Such a trade-off will constrain the adaptation of local thrips populations to ambient climatic conditions.

A potential criticism of such work is that the relationship between development rate and temperature is not strictly linear (e.g. Lamb, 1992). While this may result in problems with the estimation of DDR and $\mathrm{T}_{\min }$, it does allow us to directly compare our results with previously published studies.

We speculate that there are two possible explanations why there is such wide variation in $\mathrm{T}_{\min }$ and DDR reported in the lit- 
$\mathbf{a}$

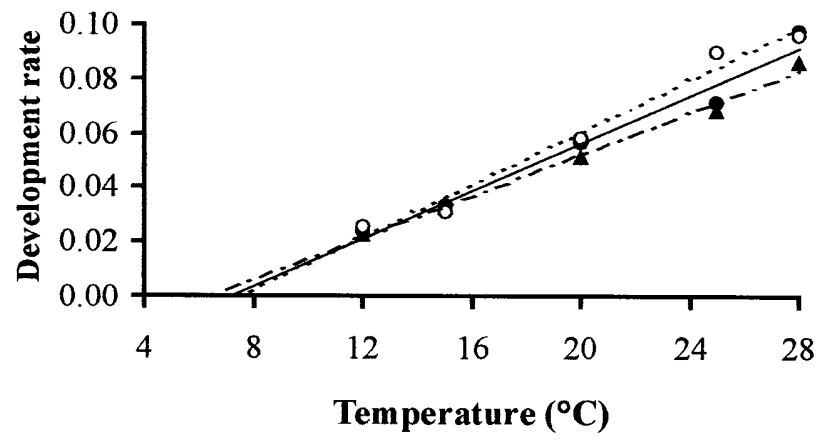

b

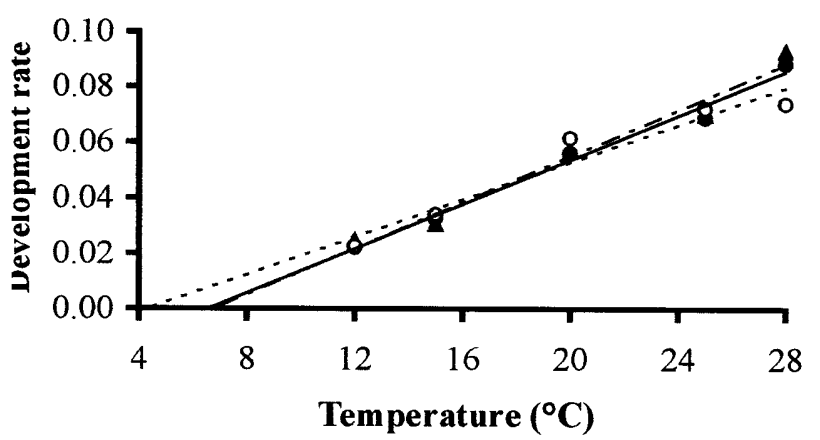

c

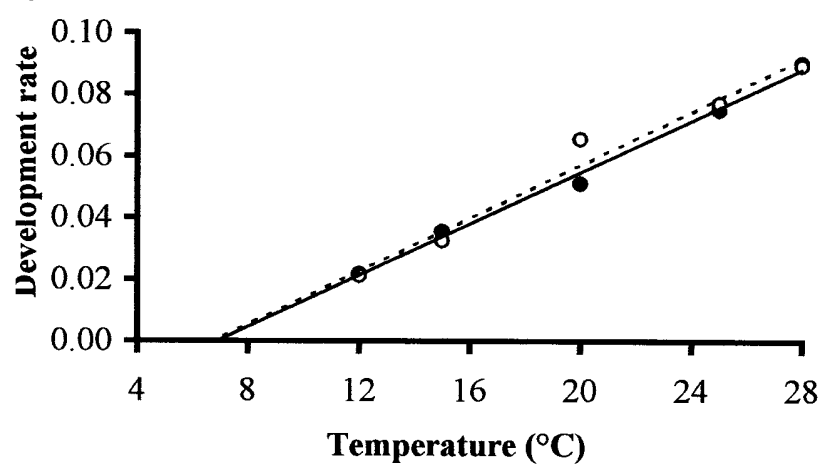

Fig. 1. The relationship between mean development rate and temperature for a) Thrips tabaci, b) Thrips major and c) Frankliniella occidentalis. The best fit regression lines are shown for

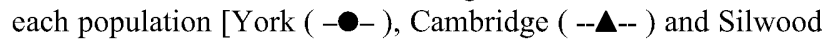
Park (- - O- )].

erature, but not in our study. First, there may be geographic variation in $\mathrm{T}_{\min }$ and/or DDR resulting from local adaptation to ambient climatic conditions. Honěk (1996) calculated $\mathrm{T}_{\min }$ and DDR values for 335 insect species, and found that there was a significant negative relationship between latitude and $T_{\min }$. While not significant, there was also strong evidence that there was a positive relationship between latitude and insect DDR. The absence of variation in $T_{\min }$ and DDR among English thrips populations may therefore be a sign of a lack of appreciable differences in local climatic conditions, and the wide differences among the published literature reflects the wide climatic conditions to which the thrips populations studied are adapted. However, there are several studies where intraspecific variation in DDR and $T_{\min }$ from widely distributed insect populations has not been found (Tauber et al., 1987; Lamb et al., 1987; Lamb \& MacKay, 1988; Mogi, 1992; Groeters, 1992; Royer et al., 2001). Second, the differences in $\mathrm{T}_{\min }$ and $\mathrm{DDR}$ may result from varia-

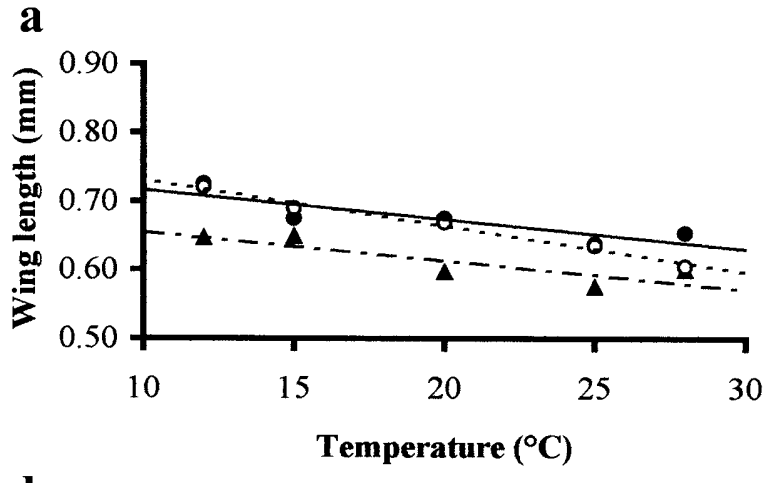

b

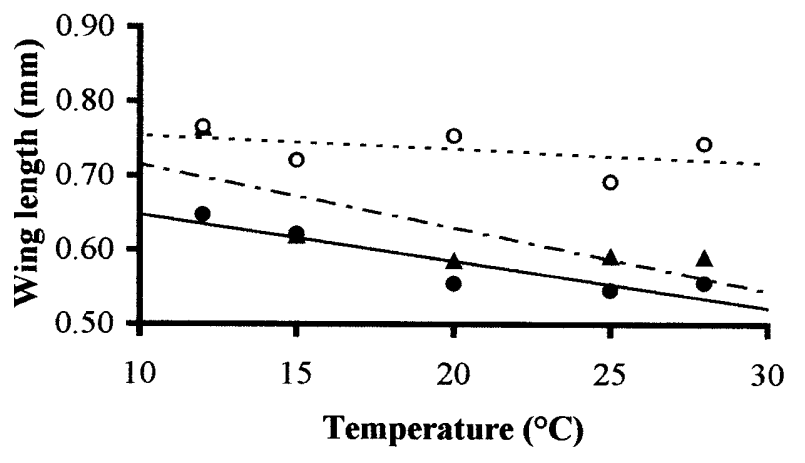

c

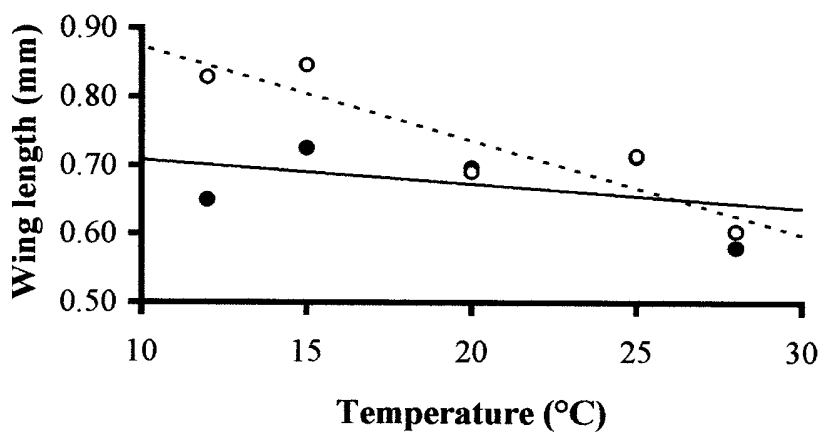

Fig. 2. The relationship between mean wing length and rearing temperature for a) Thrips tabaci, b) Thrips major and c) Frankliniella occidentalis. The best fit regression lines are shown for each population [York (--), Cambridge (-- - -) and Silwood Park (--O- )].

tion in host plant nutritional quality. There is much evidence that host plant species and cultivar can alter insect development rates (e.g. de Jager et al., 1993; Nakao, 1994; Tsai et al., 1995; Trematerra et al., 1996; Bergh \& le Blanc, 1997; de Kogel et al., 1999), and while we used the same host plant for all trials, other studies have used a variety of host plants.

Trudgill (1995) provided a functional explanation for tradeoffs between DDR and $\mathrm{T}_{\text {min }}$, arguing that genotypes with a lower $\mathrm{T}_{\min }$ will have a lower development rate at the optimal temperature for development than genotypes with a higher $\mathrm{T}_{\min }$. In consequence, the slope of the line will be lower for genotypes with a lower $T_{\text {min }}$, resulting in the negative relationship between DDR and $T_{\min }$. However, a negative relationship between $T_{\min }$ and DDR could also result if host plant quality does not act equally at all temperatures on development rate (i.e. if poor host plant quality has a greater impact on development rate at lower temperatures). There is some evidence for the first explanation, as 


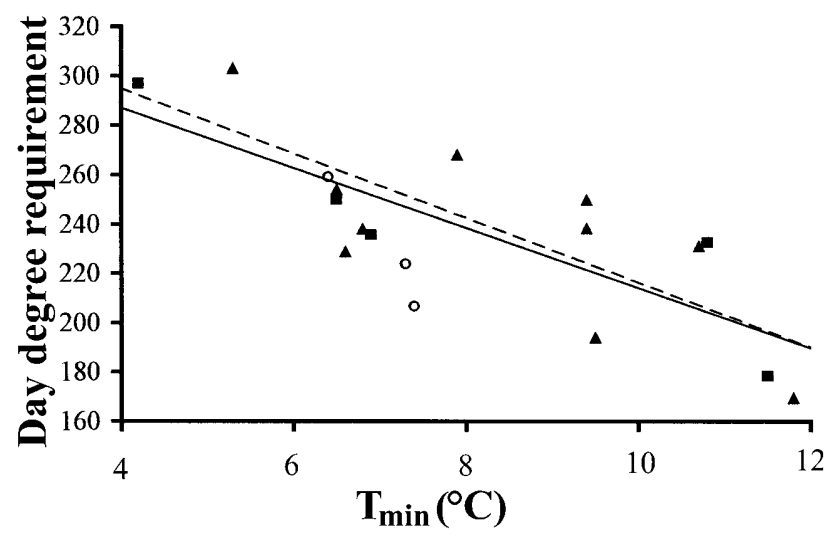

Fig. 3. The relationship between day degree requirement and threshold developmental temperature for populations of $F$. occi-

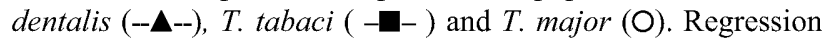
lines are shown for F. occidentalis and T. tabaci.

Tauber et al. (1987) found a negative relationship between $T_{\min }$ and DDR for five identically reared populations of the green lacewing, Chrysopa oculata. While further study is clearly required to disentangle these alternative explanations, the trade-off between DDR and $\mathrm{T}_{\min }$ will act to constrain adaptation to local conditions; an insect cannot both develop quickly and develop at lower temperatures.

Irrespective of the underlying reasons for the observed differences in thermal requirements, this study illustrates major differences in $\mathrm{T}_{\min }\left(4.9-11.8^{\circ} \mathrm{C}\right.$ for $F$. occidentalis; $4.2-11.5^{\circ} \mathrm{C}$ for T. tabaci) and DDR (169-274 for F. occidentalis, 191-297 for T. tabaci) for each of these two thrips species. It is clear that such variation will have a huge effect on the predicted potential for population growth of either pest species. Understanding the relationships between insects and temperature is a critical component of pre-emptive pest management, and with the current predictions for climate change this importance is likely to rise. We suggest that co-ordinated studies of several populations of pest insects raised under uniform conditions (i.e. host plant cultivar, relative humidity, light regime) are necessary if we are to quantify variation in the relationships between insect development rates and temperature.

ACKNOWLEDGEMENTS. We would like to thank Jude Bennison (ADAS, Boxworth, Cambridgeshire) and Rob Jacobson (HRI, Cawood, Yorkshire) for help with insect collecting, Emma Wittmann for advice on the analyses, and Tilly Collins, John Lawton, Simon Leather and two anonymous referees for commenting on the manuscript.

\section{REFERENCES}

Addo-Bediako A., Chown S.L. \& Gaston K.J. 2000: Thermal tolerance, climatic variability and latitude. Proc. Roy. Soc. Lond. B 267: 739-745.

AtKinson D. 1994: Temperature and organism size - a biological law for ectotherms. Adv. Ecol. Res. 25: 1-58.

Ayers M.P. \& Scriber J.M. 1994: Local adaptation to regional climates in Papilio canadensis (Lepidoptera: Papilionidae). Ecol. Monogr. 64: 465-482.

BAKER C.R.B. \& Miller G.W. 1978: The effect of temperature on the post-diapause development of four geographical populations of the European cherry fruit fly (Rhagoletis cerasi). Entomol. Exp. Appl. 23: 1-13.
Baker R.H., Cannon R.J. \& Walters K.F. 1996: An assessment of the risks posed by selected non-indigenous pests to UK crops under climate change. Asp. Appl. Biol. 45: 323-330.

Bergh J.C. \& LE BlanC J.P.R. 1997: Performance of Western Flower Thrips (Thysanoptera: Thripidae) on cultivars of miniature rose. J. Econ. Entomol. 90: 679-688.

Birkmoe T. \& LeinaAs H.P. 2001: Growth and development in a high Arctic Collembola: adaptive variation in local populations living in contrasting thermal environments. Ecol. Entomol. 26: 100-105.

Bryan D.E. \& SMith R.F. 1956: The Frankliniella occidentalis complex in California (Thysanoptera: Thripidae). Univ. Calif. Publ. Entomol. 10: 359-410.

Campbell A., Frazer B., Gilbert N., Gutierrez A. \& Mackauer M. 1974: Temperature requirements of some aphids and their parasites. J. Appl. Ecol. 11: 431-438.

CANNON R. 1998: The implications of predicted climate change for insect pests in the UK, with emphasis on non-indigenous species. Glob. Change Biol. 4: 785-796.

CHILdERs C.C. 1997: Feeding and oviposition injuries to plants. In: Thrips as Crop Pests. (Ed. Lewis T.) Cambridge, CAB International, pp. 505-538.

Crawley M.J. 1993: GLIM for Ecologists. Blackwell Scientific Publications, Oxford, 379 pp.

DANKS H.V. 2000: Measuring and reporting life cycle duration in insects and arachnids. Eur. J. Entomol. 97: 285-303.

Edelson J.V. \& Magaro J.J. 1988: Development of onion thrips Thrips tabaci as a function of temperature. Southwest Entomol. 13: 171-176.

EPPO/CABI 1992: Quarantine Pests for Europe (Ed. by Smith I.M., McNamara, D.G., Scott P.R. \& Harris K.M.) CAB International, Wallingford, UK, pp. 267-271.

Gaum W., Giliomee J. \& Pringle K. 1994: Life history and life tables of Western Flower Thrips Frankliniella occidentalis (Thysanoptera: Thripidae) on English cucumbers. Bull. Entomol. Res. 84: 219-224.

GILbert N. \& RAworth D.A. 1996: Insects and temperature - a general theory. Canad. Entomol. 128: 1-13.

GroEters F.R. 1992: Geographical conservatism of development rate in the milkweed-oleander aphid, Aphis nerii. Acta Oecol. 13: 649-661.

HoNĚK A. 1996: Geographical variation in thermal requirements for insect development. Eur. J. Entomol. 93: 303-312.

Jager de C., Butot R., Jong de T., Klinkhamer P. \& van der MeidDEn E. 1993: Population growth and survival of Western Flower Thrips, Frankliniella occidentalis Pergande (Thysanoptera: Thripidae), on different chrysanthemum cultivars. $J$. Appl. Entomol. 115: 519-525.

Jaroš́́ V., Koliáš M., Lapchin L., Rochat J. \& Dixon A.F.G. 1997: Seasonal trends in the rate of population increase of Frankliniella occidentalis (Thysanoptera: Thripidae) on cucumber. Bull. Entomol. Res. 87: 487-495.

JefrRee E. \& JefrRee C. 1994: Temperature and the biogeographical distributions of species. Funct. Ecol. 8: 640-650.

KATAYAMA H. 1997: Effect of temperature on development and oviposition of Western Flower Thrips Frankliniella occidentalis (Pergande). Japan J. Appl. Entomol. Zool. 41: 225-231.

KIRK W.D. 1996: Thrips. Naturalists' Handbooks 25. Richmond Publishing Company, Slough, $70 \mathrm{pp}$.

Kogel de W., Bosco D., van der Hoek M., Mollema C. 1999: Effect of host plant on body size of Frankliniella occidentalis (Thysanoptera: Thripidae) and its correlation with reproductive capacity. Eur. J. Entomol. 96: 365-368.

LAMB R.J. 1992: Developmental rate of Acyrthosiphon pisum (Homoptera, Aphididae) at low temperatures - implications 
for estimating rate parameters for insects. Environ. Entomol. 21: $10-19$.

LAMB R.J. \& MACKaY P.A. 1988: Effects of temperature on development rate and adult weight of Australian populations of Acyrthosiphon pisum (Harris) (Homoptera: Aphididae). Mem. Entomol. Soc. Can. 146: 49-55.

Lamb R.J., MacKay P.A. \& Gerber G.H. 1987: Are development and growth of pea aphids, Acyrthosiphon pisum, in North America adapted to local temperatures? Oecologia 72: $170-177$

Lewis T. (ed.) 1997: Thrips as Crop Pests. Cambridge, CAB International, $740 \mathrm{pp}$.

Lowry V.K., SMith J.R. \& Mitchell F.L. 1992: Life-fertility tables for Frankliniella fusca (Hinds) and F. occidentalis (Pergande) (Thysanoptera: Thripidae) on peanut. Ann. Entomol. Soc. Amer. 85: 744-754.

LUBLINKHOF J. \& FOSTER D.E. 1977: Development of reproductive capacity of Frankliniella occidentalis reared at three temperatures. J. Kans. Entomol. Soc. 50: 313-316.

MCDonald J., Bale J. \& Walters K. 1998: Effect of temperature on development of the Western Flower Thrips, Frankliniella occidentalis (Thysanoptera: Thripidae). Eur. $J$. Entomol. 95: 301-306.

Mogr M. 1992: Temperature and photoperiod effects on larval and ovarial development of New Zealand strains of Culex quinquefasciatus (Diptera: Culicidae). Ann. Entomol. Soc. Amer. 85: 58-66.

Mound L.A. \& KibBy G. 1998: Thysanoptera: An Identification Guide, 2nd edition. CAB International, London, $70 \mathrm{pp}$.

MuraI T. 2000: Effect of temperature on development and reproduction of the onion thrips, Thrips tabaci Lindeman (Thysanoptera: Thripidae), on pollen and honey solution. Appl. Entomol. Zool. 35: 499-504.

NAKAO S. 1993: Effects of temperature and photoperiod on wing form determination and reproduction of Thrips nigropilosus (Thysanoptera: Thripidae). Appl. Entomol. Zool. 28: 463-472.

NAKAO S. 1994: Effects of food type on wing form determination and development in female Thrips nigropilosus (Thysanoptera: Thripidae). Appl. Entomol. Zool. 29: 273-278.

Risn van P., Mollema C. \& Steenhuis-Broers G. 1995: Comparative life history studies of Frankliniella occidentalis and
Thrips tabaci (Thysanoptera: Thripidae) on cucumber. Bull. Entomol. Res. 85: 285-297.

RobB K.L. \& PARRella M.P. 1991: Western Flower Thrips, a Serious Pest of Floriculture Crops. Proceedings of the International Conference on Thrips. February 21-23, 1989, Burlington, Vermont, USA, $243 \mathrm{pp}$.

Royer T.A., Giles K.L., Kindler S.D. \& Elliott N.C. 2001: Developmental response of three geographic isolates of Lysiphlebus testaceipes (Hymenoptera: Aphididae) to temperature. Environ. Entomol. 30: 637-641.

SOKAL R.R. \& RoHLF F.J. 1995: Biometry. W.H. Freeman \& Company, New York, 887 pp.

SteINer M.Y. \& Goodwin S. 1998: Methods for collecting and rearing thrips (Thysanoptera) and their natural enemies. Aust. J. Entomol. 37: 101-106.

Tauber C.A., Tauber M.J. \& Nechols J.R. 1987: Thermal requirements for development in Chrysopa oculata - a geographically stable trait. Ecology 68: 1479-1487.

Tauber M.J. \& Tauber C.A. 1978: Evolution of phenological strategies in insects: a comparative approach with ecophysiological and genetic considerations. In: Dingle H. (ed.) Evolution of Insect Migration and Diapause. Springer, New York, 343 pp.

Telfer M.G. \& Hassall M. 1999: Ecotypic differentiation in the grasshopper Chorthippus brunneus: life history varies in relation to climate. Oecologia 121: 245-254.

Trematerra P., Fontana F. \& Mancini M. 1996: Analysis of development rates of Sitophilus oryzae (L.) in five cereals of the genus Triticum. J. Stored Prod. Res. 32: 315-322.

TRIMBLE R.M. \& Lund C.T. 1983: Intra- and interpopulation variation in the thermal characteristics of preadult development of two latitudinally diverse populations of Toxorhynchites rutilus septentrionalis (Diptera: Culicidae). Can. Entomol. 115: 659-662.

TRUDGILL D.L. 1995: Why do tropical poikilothermic organisms tend to have higher threshold temperatures for development than temperate ones? Funct. Ecol. 9: 136-138.

Tsai J., Yue B., Webb S., FunderburK J. \& Hsu H. 1995: Effects of host plant and temperature on growth and reproduction of Thrips palmi (Thysanoptera: Thripidae). Environ. Entomol. 24: $1598-1603$. 